\title{
The effect of a biostimulator on the growth, development and yield of oily sunflower
}

\author{
Yuldasheva Zulfiya Kamalovna ${ }^{1}$, Karabaeva Dilfuza Jo'raevna ${ }^{2}$, Avezov Muhriddin Normamat ogli ${ }^{3}$ \\ ${ }^{1}$ Tashkent State Agrarian University, Associate Professor of Soybeans and Oilseeds Crops candidate of \\ agricultural sciences, zkamalovna@mail.ru \\ ${ }^{2}$ Termez State University, Teacher of the Department of Botany, qaraboeva76@gmail.com
}

${ }^{3}$ TerSU student

\begin{abstract}
The article examines the effect of VL-77 biostimulator on the growth, development and yield of oilseed sunflower variety "Dilbar" in the conditions of typical irrigated gray soils of Tashkent region by cultivating seeds for sowing in the field in 6 different doses and 2-4 leaves. The stems and leaves were processed.

Keywords. Oily sunflower, variety, seeds, options, drug, biostimulator, consumption rate, yield, basket, growing season, tray.

\section{Introduction}

In our country, special attention is paid to the consistent development of the chemical industry, the expansion of production of various chemical products for agriculture. Our scientists are creating new types of fertilizers and biostimulants, produced on the basis of local raw materials, which accelerate the growth of plants, increase their productivity, resistance to various diseases and frost. The degree to which the problem has been studied. VL-77 is designed for processing seeds and growing crops, increasing the effectiveness of pesticides and fertilizers by $20-30 \%$; increases productivity, increases protein, gluten, sugar and other substances in the crop; increases disease resistance of crops by 1.5-2 times; increases the heat resistance of crops by $26-34 \%$ and drought resistance by $35-40 \%$; improves the natural appearance of fruits and vegetables, prolongs shelf life. With timely and high-quality application of the drug, crop yields increase by $10-30 \%$ per hectare.

\section{Main part}

Research conditions and methods. Field experiments were conducted at the experimental farm of the State Unitary Enterprise "Center for Innovative Development and Consulting in Agriculture" under the Tashkent State Agrarian University. Field experiments are based on the methodology of UzPITI "Methods of conducting field experiments" (2007) and the recommendations of the Experimental Station of Oilseeds and Fiber Crops of Uzbekistan. Lukomes's manual "Methods of proving the use of agrotechnical opitov with oil cultures" (2010) was used. Dilbar variety, VL-77 (Vimpel) biostimulator, included in the State Register of sunflower, was studied. VL77 (Vimpel) biostimulator - A plant growth stimulator. Ingredients: Polyethylene oxides - $770 \mathrm{~g} / 1$ and washed salt humic acids $-30 \mathrm{~g} / 1$. Research results. In order to study the effect of VL-77 biostimulator on the germination of oilseed sunflower seeds "Dilbar", the seeds were selected and 100 sunflower seeds were treated in each sand tray with biostimulator in 6 different doses on January 29. planted and placed in a thermostat at a temperature of $20^{\circ}$.
\end{abstract}

Diagram - 1

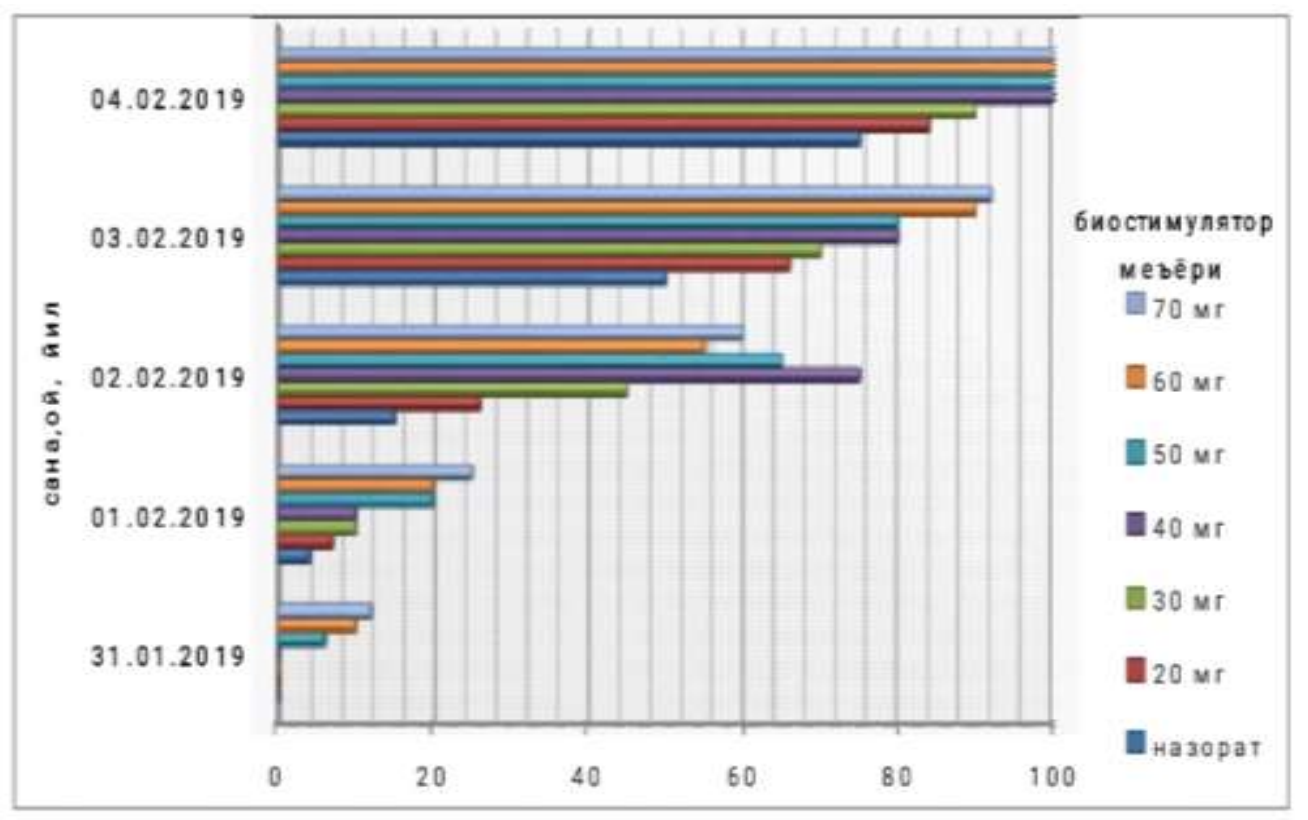


Effect of biostimulator VL-77 on seed germination of Dilbar variety (in laboratory conditions)

On January 31, 2 days after sowing, the seeds in trays 5, 6 and 7 appeared on the sand surface. In these variants 6-12 seeds germinated. On February 1, seeds were germinated in all trays in the experiment, and most seed germination was observed in trays (4-7 units) that consumed a control and $20 \mathrm{mg} /$ ha bilstimulator.

In the fifth tray using a biostimulator at a dose of 50,60.70 mg, the initial stem of 20-25 seeds per 100 seeds was observed on the surface of the sand on 1 February, while 100 seeds were found to germinate on 4 February.

The use of $20 \mathrm{mg}$ of the biostimulator did not give good results, at this rate, 84 seeds germinated in the tray using the biostimulator on February 4, which was 9 seeds more than in the control tray.

This means that the biostimulator has a positive effect on the germination power of seeds and helps to accelerate

their germination.

It was observed that the effect of the biostimulator on the formation of the harvest basket, its diameter, number of seeds and weight was significantly higher.

Table 1

Indications for the effect of biostimulants on the yield elements of sunflower

\begin{tabular}{|c|c|c|c|c|c|c|c|}
\hline Options & $\begin{array}{l}\text { Biostimulator } \\
\text { consumption } \\
\text { rate, grams } \\
\text { ha }\end{array}$ & $\begin{array}{l}\text { Basket } \\
\text { width, cm }\end{array}$ & $\begin{array}{l}\text { Number of seeds } \\
\text { in the basket, pcs }\end{array}$ & $\begin{array}{l}\text { Weight of seeds } \\
\text { in the basket, } \\
\text { grams }\end{array}$ & $\begin{array}{l}\text { The duration } \\
\text { of the growth } \\
\text { period }\end{array}$ & $\begin{array}{l}\text { Weight of } \\
1000 \text { seeds, } \\
\text { grams }\end{array}$ & $\begin{array}{l}\text { Seed yield, } \\
\text { ts / ha }\end{array}$ \\
\hline 1 & назо & 29,0 & 1028,0 & 85,3 & 122 & 83,0 & 25,5 \\
\hline 2 & 200 & 32,5 & 1304,0 & 116,8 & 119 & 89,6 & 27,8 \\
\hline 3 & 300 & 34,6 & 1325,0 & 119,9 & 118 & 90,5 & 29,7 \\
\hline 4 & 400 & 36,0 & 1340,0 & 122,3 & 115 & 91,3 & 31,0 \\
\hline 5 & 500 & 37,7 & 1367,0 & 125,8 & 115 & 92,0 & 32,8 \\
\hline 6 & 600 & 38,0 & 1315,0 & 118,5 & 115 & 90,1 & 30,0 \\
\hline
\end{tabular}

The front of the harvest baskets is usually disc-shaped and slightly raised, while the back is slightly deeper. When the width of the front of the baskets was measured, it was found that the control variant was $29.0 \mathrm{~cm}$, which was narrower than all the variants in the experiment. In the seventh variant applied at $200 \mathrm{~g} / \mathrm{ha}, 3.5 \mathrm{~cm}$ compared to the control variant, $5.6 \mathrm{~cm}$ in the variant applied at $300 \mathrm{~g} / \mathrm{ha}, 7.0 \mathrm{~cm}$ in the variant applied at $400 \mathrm{~g} / \mathrm{ha}, 8.7 \mathrm{~cm}$ in the variant applied at $500 \mathrm{~g} / \mathrm{ha}$, and $600 \mathrm{gram} / \mathrm{ha}$ was found to be $9.0 \mathrm{~cm}$ larger in the applied variant. Increasing the amount of biostimulator to 600 grams / ha led to an increase in the diameter of the baskets and their weight.

The stem of the Dilbar variety of sunflower does not have the ability to branch and form additional baskets, ie bachki, but the applied biofertilizer and biostimulator stems formed additional branches and baskets in a very small size. The experiment in which the VL-77 biostimulator was used did not produce horns and baskets in the variant where control and biofertilizer at the rate of $200 \mathrm{~g} / \mathrm{ha}$ were used. Produced 0.1 units in the $300 \mathrm{gram} / \mathrm{ha}$ and 400 gram / ha variants, and 0.2 in the 500 and 600 gram / ha variants.

The economic ripening of the baskets varied depending on the norm of application of the biostimulator. Yield ripening was observed in 122 days in the control variant, 119 days in the variant with a biostimulant content of $200 \mathrm{~g} / \mathrm{ha}$ in 119 days in the variant with $300 \mathrm{~g} / \mathrm{ha}$, and 115 days in the variant with 400, $500 \mathrm{and} 600 \mathrm{~g} / \mathrm{ha}$. Yield ripening was found to be 3-7 days later than in the control variant where the biostimulator was used.

It was found that the effect of biostimulator norm on the weight of 1000 seeds was significant. In the control variant without biostimulator, the weight of 1000 seeds was 83.0 grams, while in the variants with biostimulator, the weight of seeds was observed. Weight of 1000 seeds was 6.6 grams in the case of $200 \mathrm{~g} / \mathrm{ha}$ biostimulator, 7.5 grams in the case of $300 \mathrm{~g} /$ ha biostimulator, 8.3 grams in the case of $400 \mathrm{~g} /$ ha biostimulator, $500 \mathrm{~g} / \mathrm{ha}$ in the case of biostimulator. The variant with a biostimulator of $9.0 \mathrm{~g}$ and $600 \mathrm{~g} / \mathrm{ha}$ weighed $7.1 \mathrm{~g}$ heavier.

A positive effect of VL-77 biostimulator on productivity was observed. In the control variant, the yield was $25.5 \mathrm{ts} / \mathrm{ha}$, in the variant with a biostimulator at the rate of $200 \mathrm{~g} / \mathrm{ha}-27.8 \mathrm{ts} / \mathrm{ha}$, in the variant with a dose of $300 \mathrm{~g} / \mathrm{ha}-29.7 \mathrm{ts} / \mathrm{ha}$, in the variant with the norm of $400 \mathrm{~g} / \mathrm{ha}-31,7 \mathrm{ts} / \mathrm{ha}, 32.8 \mathrm{ts} / \mathrm{ha}$ from the $500 \mathrm{gram} /$ ha norm and 30.0 ts / ha from the 600 gram / ha variant. It can be seen that in the variants using a biostimulator, an increase in yield was observed at the expense of the biostimulator. In the control variant of the biostimulator, the yield increased by 2.3 ts / ha per hectare in the 200 gram / ha variant, by 4.2 ts / ha in the 300 gram / ha variant, and by 5.5 ts / ha in the 400 gram / ha variant. ts / ha, an increase of 7.3 ts / ha compared to the variant with a norm of 500 grams / ha and an increase of 4.5 ts / ha compared to the variant with a norm of $600 \mathrm{grams} / \mathrm{ha}$. 


\section{Conclusion}

The use of VL-77 biostimulator had a positive effect on the growth and development and yield of Dilbar variety of sunflower, the plants were larger and the number of leaves was also higher. When the biostimulator dose of $500 \mathrm{~g}$ / ha was applied, the baskets were large, the number of seeds was large, and the weight of the seeds was heavy, and the yield was high, and when this amount was increased or decreased, the baskets were smaller and the number of seeds decreased.

\section{References:}

1.Dospekhov B.A. Field experiment technique (with the basics of statistical processing of research results) 5th ed., Rev and add - M. Agropromizdat, 1985 - $351 \mathrm{p}$

2.Korotetskiy A.I. Koltsov S.A. "Pennant" plant growth stimulator "Lugansk, Dolina, 2014, 18 pp.

3.Lukomets V.M. Methodology for conducting field agrotechnical experiments with oil crops V.M. Lukomets, N.M. Tishkov, V.F. Baranov and others - Krasnodar, 2010 - 327 p.

4.Lukhmenev V.P. Influence of fertilizers, fungicides and growth regulators on sunflower productivity / V.P. Lukhmenev . News of the Orenburg State Agrarian University - 2015 - No. 1- P. 41-46.

5.5.Nurmatov Sh.N., Mirzajanov Q. etc. Methods of conducting field experiments ", 2007. 